\title{
In-vitro culture of hamster epididymal epithelium and induction of sperm motility
}

\author{
H. D. M. Moore, T. D. Hartman and C. A. Smith \\ $M R C / A F R C$ Comparative Physiology Group, Institute of Zoology, \\ The Zoological Society of London, Regent's Park, London NW1 4RY, U.K.
}

\begin{abstract}
Summary. Epithelium from the proximal corpus region of the epididymis of adult hamsters was cultured in modified RPMI 1640 medium supplemented with growth factors and androgens at $37^{\circ} \mathrm{C}$ in $5 \% \mathrm{CO}_{2}$ in air. Prepared plaques of epithelium formed spheres of tissue with epithelial cells outermost. At the light and electron microscope level, these epithelial balls displayed morphology consistent with continued secretory and absorptive function. After 3-5 days, cultured cells either plated out over the bottom of plastic wells or formed vesicles which expanded as their interior became fluid filled.

Spermatozoa recovered from the caput epididymidis were co-cultured with epithelium. After 8 and $24 \mathrm{~h}$, a proportion of spermatozoa (30\%) exhibited slow but persistent flagellum beats with slow progressive motility. Spermatozoa in control incubations were immotile. This change in motility pattern would suggest that some sperm maturation processes had occurred in vitro.
\end{abstract}

\section{Introduction}

Sperm maturation within the mammalian epididymis is dependent on the luminal milieu created by the secretory and absorptive activity of the lining epithelial cells of the duct (see Bedford \& Cooper, 1978; Brooks, 1981; Holt, 1982; Moore, 1983). This microenvironment, which is under the contol of androgens (see Orgebin-Crist et al., 1975; Moore \& Bedford, 1979a; Moore, 1981), has proved difficult to probe continuously in vivo by, for instance, micropuncture technique (Hinton \& Setchell, 1981), without perturbing epididymal function. It is clear, however, that the development of sperm fertilizing ability is associated with a host of changes both to epididymal spermatozoa (Bedford, 1975; Moore 1983) and luminal fluid as illustrated by the complex array of proteins displayed by techniques such as two-dimensional polyacrylamide gel electrophoresis (Volgmayr et al., 1985).

In other organ systems (e.g. kidney), in-vitro culture conditions have proved invaluable as a method for dissecting complex biochemical mechanisms. Previous attempts to culture epididymal principal cells in vitro have shown that normal morphological features and some biochemical function (e.g. steroid synthesis) can be maintained for several days (Kierszenbaum et al., 1981; Klinefelter et al., 1982; Joshi, 1985). Furthermore, the organ culture of epididymal tubules, in which morphological integrity of epithelium remains largely intact, will induce some degree of sperm maturation(Orgebin-Crist \& Jahad, 1979; Cuasnicú et al., 1984), but this culture methods allows only limited access to the tubule lumen. To provide a simplified system to study epididymal function, we describe here a cell culture preparation in which the ultrastructural epithelial architecture of the hamster epididymis remains initially intact. This culture method has been used to investigate changes in the motility of hamster spermatozoa that accompany their maturation.

\section{Materials and Methods}

Culture preparation. Adult male golden hamsters (Mesocricetus auratus) were killed with an intraperitoneal injection of pentobarbitone sodium ( $0.6 \mathrm{ml}$ Sagatal: May and Baker, Dagenham, U.K.) 


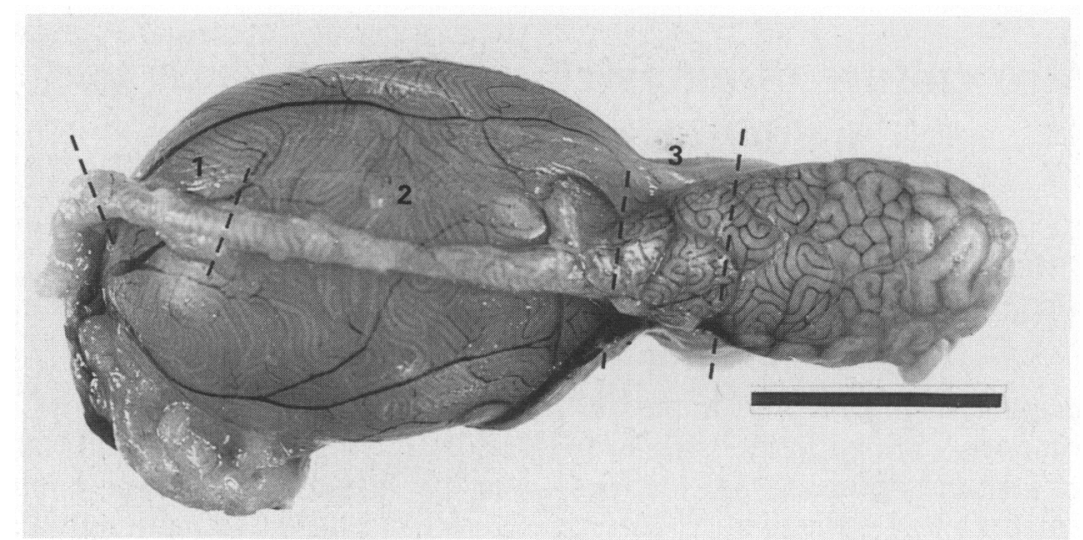

Fig. 1. Photograph of a dissected testis and epididymis. 1, proximal corpus; 2, distal corpus; 3 , proximal cauda epididymidis. $\mathrm{Bar}=1 \mathrm{~cm}$.

and epididymides were excised and dissected free of fat. The proximal corpus region (see Fig. 1) from each duct was removed and placed in a small glass dish covered with culture medium containing $10 \mathrm{mg}$ collagenase $/ \mathrm{ml}$ (Sigma, Poole, U.K.) and incubated at $37^{\circ} \mathrm{C}$ in $5 \% \mathrm{CO}_{2}$ in air for $2 \mathrm{~h}$. The tissue was transferred to a small plastic Petri dish, covered with fresh medium and gently swirled around to dissociate the tubules from the remaining connective elements. Tubule fragments (5-10 $\mathrm{mm}$ in length) were aspirated into fresh medium in a Petri dish and, using a stereomicroscope ( $\times 25 \mathrm{mag}$.) and 26-gauge needles, were ruptured lengthwise to give plaques of epithelium which were washed free of spermatozoa and then transferred to fresh medium for incubation at $37^{\circ} \mathrm{C}$ in $5 \% \mathrm{CO}_{2}$ in air. Within $1-2 \mathrm{~h}$, these pieces of epithelium formed balls of tissue with epithelium facing outwards. An alternative method was to transfer tubule fragments to $10 \mathrm{ml}$ medium in a $25-\mathrm{ml}$ plastic universal tube which was then shaken vigorously for $10 \mathrm{sec}$. The medium containing tissue fragments was placed in a Petri dish and appropriate pieces of epithelium were transferred into fresh medium for incubation. For experiments, pieces of tissue (20-30 pieces) were placed in $0.5 \mathrm{ml}$ medium in 24-well culture plates (Linbro, Flow Laboratories, Rickmansworth, U.K.). The cultures were maintained by replacing medium every other day.

Culture medium. Culture medium was RPMI 1640 (Gibco U.K. Ltd, Uxbridge, U.K.) supplemented with $10 \%$ fetal calf serum and containing $1 \mu \mathrm{M}$-sodium pyruvate, $100 \mathrm{nM}$-insulin, $200 \mathrm{~nm}$-hydrocortisone, $200 \mathrm{nM}$-testosterone, $1 \mu \mathrm{M}$-dihydrotestosterone, $5 \mu \mathrm{g}$ transferrin $/ \mathrm{ml}$ and $1 \mu \mathrm{g} r$ retinol $/ \mathrm{ml}$. Stock solutions of steroids and retinol were made up in absolute alcohol (final concentration in medium $0.05 \%)$ before addition to RPMI. The medium was filtered $(0.22 \mu \mathrm{m}$ Millipore filter) and supplemented with streptomycin and penicillin (20000 i.u.) and stored at $4^{\circ} \mathrm{C}$.

Microscopy. At various times after the start of culture (see 'Results'), tissue was fixed for light and electron microscopy by replacing medium with $2 \%$ glutaraldehyde in $0.05 \mathrm{M}$-phosphate buffer ( $\mathrm{pH} 7 \cdot 3 ; 330$ mosmol by addition of sucrose) at $4^{\circ} \mathrm{C}$. Light microscopy was performed using a phase-contrast inverted microscope (Nikon) before tissue was post-fixed in $1 \%$ osmium tetroxide in phosphate buffer ( $\mathrm{pH} 7 \cdot 3$ ) at $4^{\circ} \mathrm{C}$ for $1 \mathrm{~h}$. Tissue was dehydrated in ethanol and embedded via propylene oxide in Epon Araldite (Mollenhauer, 1964). Ultrathin sections were cut on a Reichert Ultracut $\mathrm{E}$ ultramicrotome and sections stained with uranyl acetate and lead citrate before viewing in a Jeol 1200 Ex electron microscope.

Co-culture of epithelial cells and epididymal spermatozoa. After 2 days in culture, most of the medium covering epithelium preparations was removed (to reduce culture volume for the subsequent co-culture with spermatozoa) and replaced with a thin layer of silicone oil (Dow Corning, 

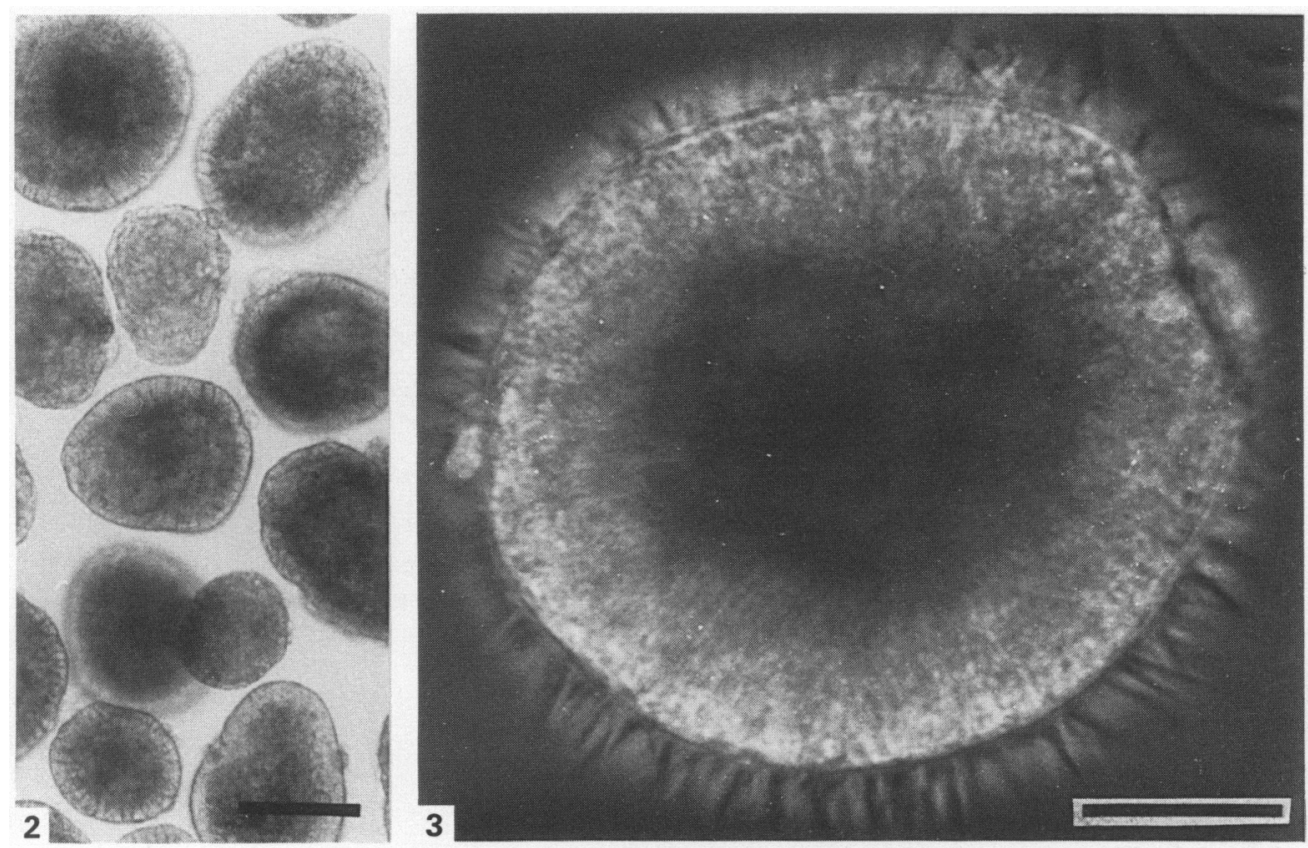

Fig. 2. A micrograph of epithelium from the corpus epididymidis $2 \mathrm{~h}$ after preparation. Epithelium can be seen to be outermost on the tissue spheres. Phase contrast. Bar $=50 \mu \mathrm{m}$.

Fig. 3. A micrograph of an epithelial ball after $24 \mathrm{~h}$ of culture. Microvilli are clearly visible on the surface. Phase contrast. Bar $=10 \mu \mathrm{m}$.

Midland, MI, U.S.A.). The proximal and distal caput regions of the epididymides were rapidly dissected from adult males and placed in $0.5 \mathrm{ml}$ culture medium under silicone oil. Spermatozoa were allowed to diffuse from the tubules (which displayed spontaneous peristaltic motion) for $10 \mathrm{~min}$. Aliquants $(50 \mu \mathrm{l})$ of spermatozoa $\left(2 \times 10^{8} / \mathrm{ml}\right)$ were placed in wells and co-cultured with epithelial cells for 4,8 or $24 \mathrm{~h}$. Controls consisted of spermatozoa incubated with 8-14-day-old cultures consisting of mainly fibroblast overgrowth, or with 3-day-old cultures incubated in the absence of androgen. Sperm concentrations within the wells ranged from $5 \times 10^{6}$ to $3 \times 10^{7} / \mathrm{ml}$.

\section{Results}

\section{Morphology of epididymal epithelial cell culture}

Gross morphology. Plaques of epididymal epithelium formed balls of tissue, with epithelial cells outermost, within $2-3 \mathrm{~h}$ of culture and, at the light microscope level, appeared morphologically intact (Fig. 2). Microvilli on the apical surface of principal cells were initially diminished by the preparation, but recovered and were clearly visible after overnight culture (Fig. 3) and remained present for the next 3-5 days. During the first $24 \mathrm{~h}$ of culture, some sloughing of unidentified cells occurred around the tissue balls but this did not apparently affect the integrity of the surface epithelium. During this period, some of the balls attached firmly to the plastic culture dish and epithelial cells exhibiting pavingstone appearance were observed under phase-contrast microscopy, spreading out from the original ball of tissue (Fig. 4). This process continued for several days until, in some instances, the initial preparation was plated out entirely over the bottom of the well.

However, some balls remained intact and, if transferred to fresh medium, developed into vesicles after about 5 days, with a transparent fluid-filled interior (Fig. 5). In some cases these vesicles 

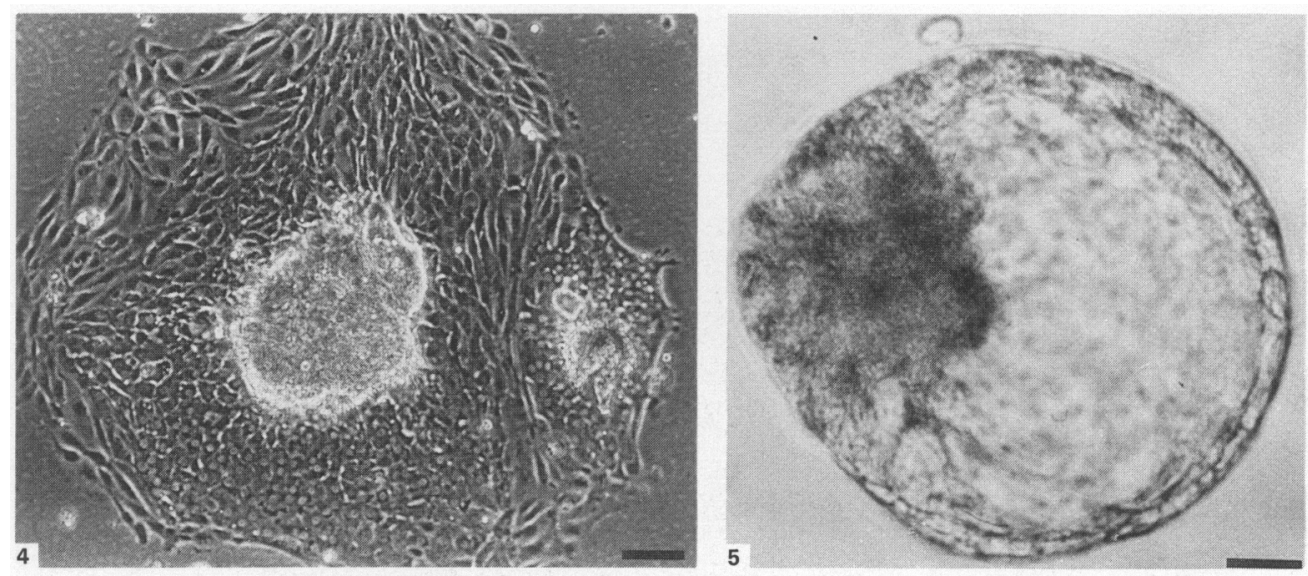

Fig. 4. A micrograph of a ball of epithelium after 3 days in culture. Epithelial cells attach and plate out on the bottom of the culture well. The perimeter of the culture was composed of non-epithelial peritubular cells. Phase contrast. Bar $=20 \mu \mathrm{m}$.

Fig. 5. A micrograph of an epithelial preparation after 5 days in culture. Instead of attaching to the culture well, some spheres become fluid filled and expanded in size. Phase contrast. $\mathrm{Bar}=20 \mu \mathrm{m}$

displayed regular contractile movements over $1-2 \mathrm{sec}$, with intervals of $30-60 \mathrm{sec}$. In the absence of androgens, epithelium preparations continued to form balls: however, there was a noticeable increase in the amount of cell sloughing and a reduction in microvilli.

Ultrastructure. Electron microscopy revealed that spheres of epithelium consisted of an outer layer of epithelial cells (principal, basal, clear and intraepithelial lymphocytes), a basal lamina and an inner sub-epithelial layer, consisting of contractile myoid cells and fibroblasts. When tissue was prepared from adult males, spermatozoa also became entrapped within the balls as they formed.

After $24-48 \mathrm{~h}$ of culture in medium containing androgen, principal cells retained morphology consistent with their function (Fig. 6a). The supranuclear cytoplasm contained well developed Golgi was tightly stacked lamellae, elongated dense mitochondria and a heterogeneous population of small and large vesicles. Furthermore, the perinuclear region and the basal cytoplasm displayed rough and smooth endoplasmic reticulum. Epithelial integrity was maintained by tight junctions situated on the lateral borders of principal cells near the apical surface. Compared with epithelium in vivo, much larger intercellular spaces were present towards the base of the surface epithelial cells in culture.

The character of the sub-epithelial cell layers varied between preparations. In all cases, a basal lamina was present; however, the proportion of fibroblasts, myoid and endothelial cells differed, as did their structural organization.

In the absence of androgens, principal cells displayed considerably more disorganization of their supranuclear cytoplasm. In particular, Golgi apparatus was vacuolated and multivesicular bodies contained membrane material. Ribosomes were seen in the intranuclear region but only small amounts of rough endoplasmic reticulum (Fig. 6b).

After 5 days in culture with androgens, tissue preparations either plated out onto the bottom of the well (with a core of tissue) or formed vesicles. The cell layer attached to the plastic consisted primarily of two types of cell (Fig. 7), the appearance of which was different from that of cells after the first 2 days in culture. A flattened collagen-secreting cell was usually in immediate contact with the plastic well and formed a continuous layer with desmosome junctions. The cytoplasm of this cell type contained extensive rough endoplasmic reticulum but little or no Golgi lamellae. Basal 


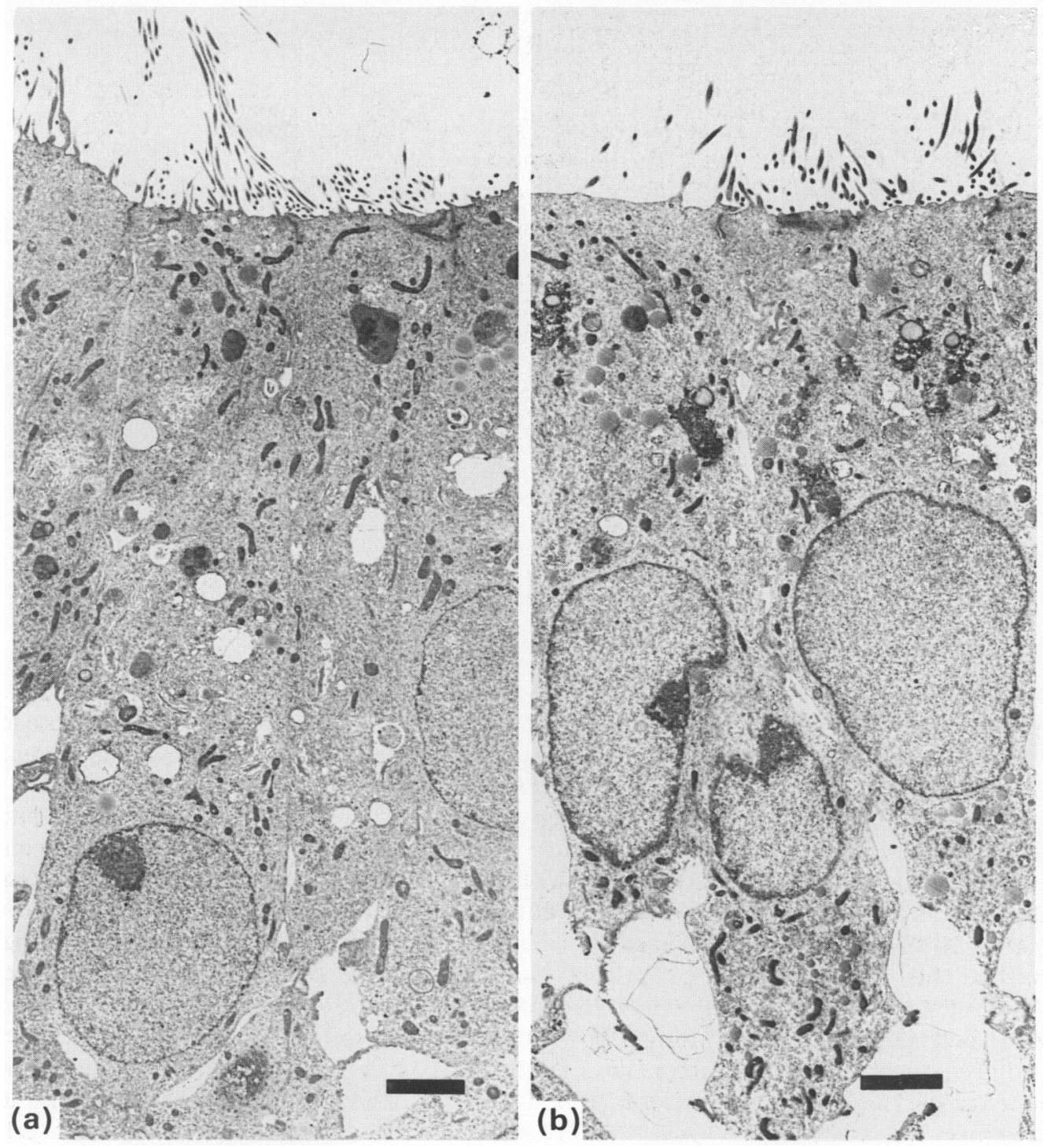

Fig. 6. Electron micrographs of principal cells from the corpus epididymidis cultured for $48 \mathrm{~h}$ (a) with androgen and (b) without androgen. In (a) morphology was consistent with continued secretory and absorptive function. In (b) the cells show disorganized Golgi membranes, an increase in lysosomes (containing membrane) and reduced amounts of rough endoplasmic reticulum. Bar $=2 \mu \mathrm{m}$.

cells were covered with flattened cells with short microvilli which were subsequently identified as principal cells (see Smith et al., 1986). These cells contained rough endoplasmic reticulum, many spherical mitochondria and often dense lipid droplets. In addition, Golgi apparatus was displayed in the apical cytoplasm of some cells.

Tissue preparations that formed vesicles after 3-5 days in culture consistently had 3 cell layers between their fluid-filled interior and the culture medium (Fig. 8). The surface epithelium consisted of principal cells with well developed microvilli and tight junctions and a full complement of 


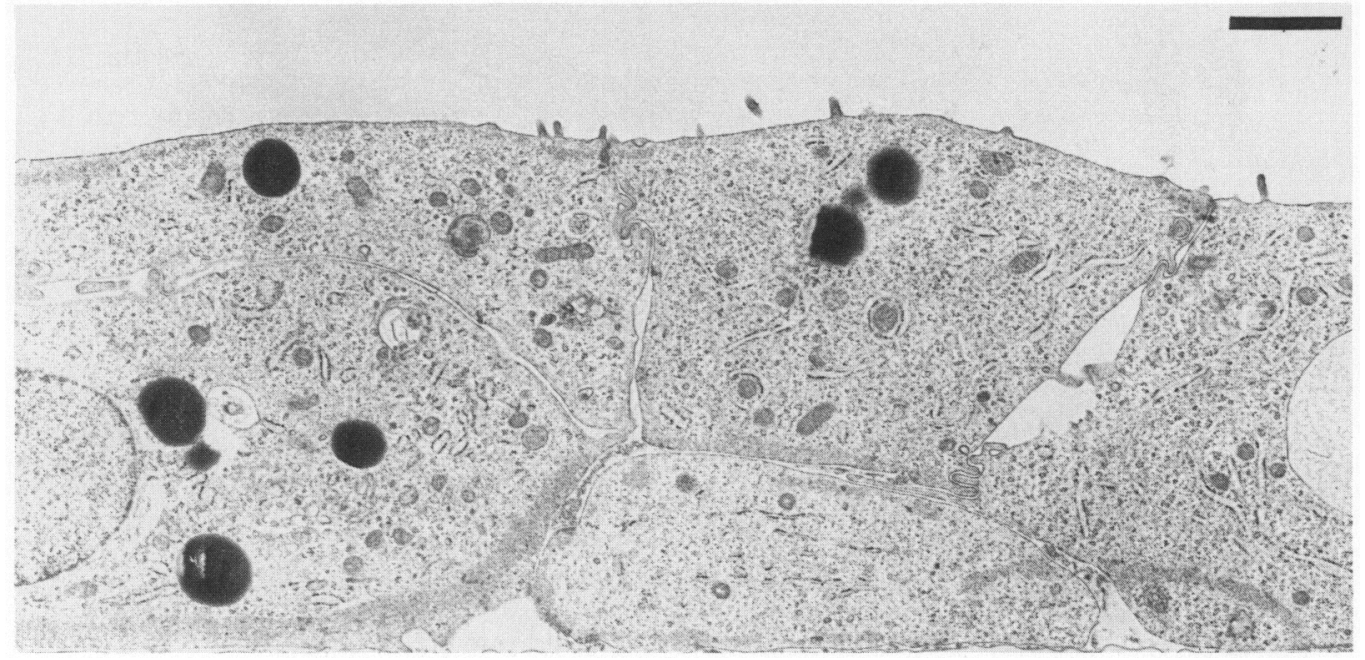

Fig. 7. Electron micrograph of cultured epithelium, plated out after 5 days in culture. A flattened principal cell type with ribosomes, lipid droplets and microvilli lies on a collagen-secreting basal cell type. $\mathrm{Bar}=20 \mu \mathrm{m}$.

organelles. The cells were less flattened than those that had plated out but were also less polarized than principal cells after just 1 day in culture. Intercellular spaces were displayed between principal cells and the underlying basal cells. The latter were linked by desmosomes.

\section{Co-culture of epithelial cells and epididymal spermatozoa}

Spermatozoa recovered from the proximal and distal regions of the caput epididymidis were immotile or showed slight twitching motility when initially placed in culture with 3-day-old epithelial cell preparations. Reproducible differences in spermatozoa were observed for the acquisition of slow but persistent flagellum movement after 8 and $24 \mathrm{~h}$ in co-culture with epithelial cells cultured for 3 days, compared with control preparations incubated for 8-14 days with androgen but displaying a fibroblast overgrowth or incubated for 3 days without androgens (Table 1).

\section{Discussion}

Since the cellular organization of an epithelium plays an integral part in its function, an important consideration in our culturing of the epididymal epithelium was to avoid procedures which initially reduce the tissue to a single cell suspension, as have been described elsewhere (Kierszenbaum et al., 1981; Klinefelter et al., 1982; Joshi, 1985). It may be argued that culture of intact lengths of epididymal tubules (Orgebin-Crist \& Jahad, 1979) could prevent spermatozoa being exposed to a potentially activating environment. However, to investigate epithelium/spermatozoa interactions fully in vitro, we felt this viewpoint was outweighed by the advantage of having immediate access to the luminal surfaces of principal cells. Hence, lengths of tubules digested free of connective tissue were severed longitudinally to produce initially plaques of epithelium which thereafter spontaneously curled inside-out to produce spheres of cells with an outer epithelial cell layer. Such a phenomenon, which is not unusual for epithelium (i.e. intestine), must presumably result from the contraction in culture of the myoid cells which surround the tubule. Indeed, spontaneous regular contractions of some of the spheres were observed. Within $24 \mathrm{~h}$, and in the presence of androgens, new tight junctions 


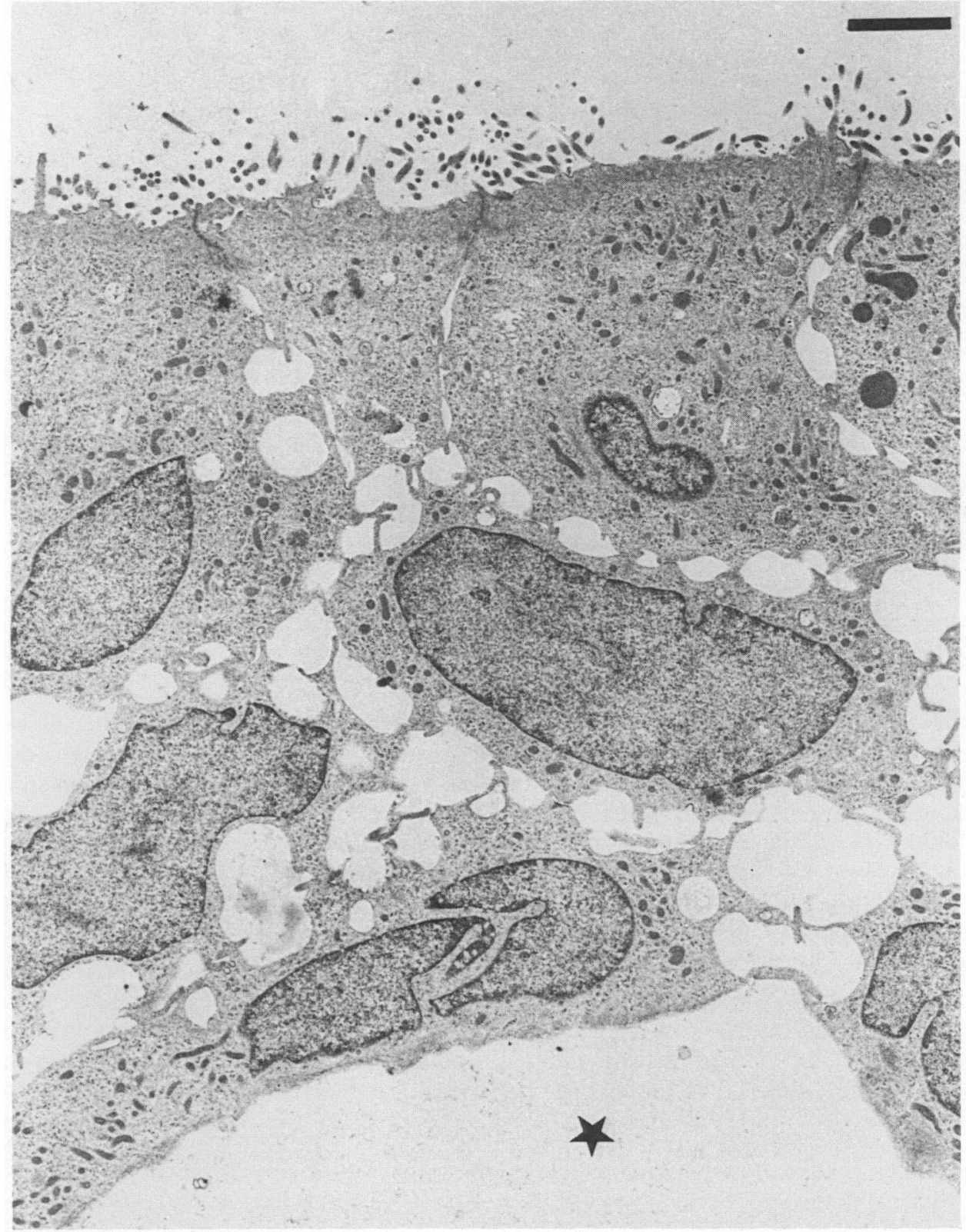

Fig. 8. An electron micrograph of an epithelium vesicle after 5 days in culture. This preparation is characterized by 3 cell layers and a fluid-filled interior $\left({ }^{*}\right)$. Principal cells with microvilli are outermost. Bar $=2 \mu \mathrm{m}$.

formed such that each ball of tissue had a continuous epithelium. Light microscope observations of the presence of microvilli protruding from the surface indicated that these preparations were displaying some normal morphological attributes. This premise was supported by the ultrastructural appearance of epithelial cells in culture for 3 days, which was consistent with absorptive and secretory function under androgen control (Hamilton, 1975; Moore \& Bedford, 1979a,b). For 
Table 1. Changes in the motility of spermatozoa from the hamster caput epididymidis after incubation with epithelium from the corpus epididymidis culture with or without androgens for 3 days, or for 8-12 days

\begin{tabular}{|c|c|c|c|}
\hline \multirow[b]{2}{*}{ Culture } & \multirow{2}{*}{$\begin{array}{l}\text { Incubation } \\
\text { time (h) }\end{array}$} & \multicolumn{2}{|c|}{ Sperm motility* } \\
\hline & & Proportion (\%) & Character \\
\hline \multirow{3}{*}{$\begin{array}{l}3 \text { days } \\
\quad+\text { androgen }\end{array}$} & 4 & $9 \pm 8$ & Twitching \\
\hline & 8 & $22 \pm 4 \dagger$ & $\begin{array}{l}\text { Twitching/slow } \\
\text { tail beat }\end{array}$ \\
\hline & 24 & $31 \pm 5 \dagger$ & $\begin{array}{l}\text { Slow tail beat } \\
\text { with progression }\end{array}$ \\
\hline \multirow{3}{*}{$\begin{array}{l}3 \text { days } \\
\quad \text {-androgen }\end{array}$} & 4 & $8 \pm 5$ & Twitching \\
\hline & 8 & $13 \pm 3$ & Twitching \\
\hline & 24 & $10 \pm 5$ & Twitching \\
\hline \multirow{3}{*}{$\begin{array}{l}\text { 8-12 days } \\
\quad+\text { androgen }\end{array}$} & 4 & $7 \pm 6$ & Twitching \\
\hline & 8 & $5 \pm 4$ & Twitching \\
\hline & 24 & $2 \pm 4$ & Twitching \\
\hline
\end{tabular}

*Means of 3 experiments. Spermatozoa were diluted in RPMI 1640 media and motility was estimated in a Neubauer counting chamber.

$\dagger$ Significantly different from controls $(P \leqslant 0.05)$.

example, cells were characterized by Golgi apparatus, rough and smooth endoplasmic reticulum, multivesicular inclusions and coated vesicles and a heterologous population of dense bodies. In general, epithelial cells remaining as a ball of tissue retained their initial cellular symmetry to a much greater extent than did cells that attached and flattened on the surface of the plastic culture well. However, in both cases, cell polarity was maintained with microvilli on the apical surface and the nucleus situated in a basal position. Epithelium surrounding the tissue spheres could be readily identified by gross morphology at the light microscope level (i.e. presence of protruding microvilli). During initial attachment to culture wells, epithelial cells also formed a characteristic 'paving stones' appearance, although definitive localization of principal cells was later carried out by immunocytochemistry (Smith et al., 1986). Both testosterone and dihydrotestosterone were normally added to medium since the exact requirement of epididymal epithelium for these steroids has not been established. In the absence of androgens, principal cells in culture exhibited degenerative morphological changes similar to those described for the androgen-deprived rodent epididymis in vivo (Moore \& Bedford, 1979a) and characterized by a reduction in microvilli, an increase in dense bodies and disorganization and a subsequent decrease in cytoplasmic membrane (Golgi, SER, RER).

After 5 days in culture with androgen, a progressive morphological dedifferentiation of most epithelial cell preparations occurred. Whether this cell refractoriness to culture was due to incorrect androgen concentrations and loss of androgen receptors or reflected a general metabolic decline due to incompatible conditions is unclear. Apparent exceptions were tissues that formed epithelial vesicles, since they developed after 3-5 days in culture and expanded steadily in size for about 14 days as a result of the accumulation of fluid within their interior. Ultrastructurally, these vesicles were different from the solid tissue spheres in that 3 layers of cells (rather than 2) were normally discernible. This epithelium displayed characteristic intercellular spaces consistent with a fluid resorptive function (Berridge \& Oschman, 1972; Wong \& Yeung, 1978).

Only spermatozoa incubated for 8-24 h with epithelium cultured with androgen for 3-5 days (i.e. functionally active) displayed and maintained slow progressive motility. It is therefore probable 
that the cultured epithelial cells modified the small drop of culture medium to induce changes in the flagellum of spermatozoa. A similar development in motility has been described for hamster spermatozoa during passage along the proximal epididymis in vivo (Horan \& Bedford, 1972) and a glycoprotein (forward motility protein) secreted by principal cells has been implicated in promoting motility maturation changes in a number of mammals (see Hoskins et al., 1979). Induction of the motility of hamster spermatozoa from the caput epididymidis has been achieved by using cauda epididymal fluid and charcoal-extracted albumin (Cornwall et al., 1985).

In conclusion, these results illustrate that changes to the character of sperm motility that occur during epididymal transit can, to a certain extent, be reproduced under in-vitro conditions when the secretory (and absorptive) functions of epithelial cells are sufficiently maintained. In this respect, retaining the architecture of the original epithelium may be important. Whether all the requirements for sperm maturation in vitro can be reproduced awaits further investigation. However, other studies indicate that cultured hamster epididymal epithelium may modify the sperm surface (Smith et al., 1986) and can induce the final development of sperm fertilizing ability (Moore \& Hartman, 1986).

This study was supported by grants from the Medical Research Council, the Agricultural and Food Research Council, The Ford Foundation and by a donation from Elf-Aquitaine (UK) plc.

\section{References}

Bedford, J.M. (1975) Maturation, transport and fate of spermatozoa in the epididymis. In Handbook of Physiology, Endocrinology V, Section 7 pp. 303-317, Eds R. O. Greep\& D. W. Hamilton. Am. Physiological Soc., Washington, D.C.

Bedford, J.M. \& Cooper, G.W. (1978) Membrane fusion events in the fertilization of vertebrate eggs. In Cell Surface Reviews, Vol. 5, pp. 65-125. Eds G. Poste \& G. L. Nicolson. North-Holland, Amsterdam.

Berridge, M.J. \& Oschman, J.L. (1972) Transporting Epithelia. Academic Press, London.

Brooks, D.E. (1981) Metabolic activity in the epididymis and its regulation by androgens. Physiol. Rev. 61, 515-555.

Cornwall, G.A., Vindivich, D. \& Chang, T.S.K. (1985). Induction and enhancement of motility in hamster caput epididymal spermatozoa. Biol. Reprod. 32, Suppl. 1, Abstr. 177.

Cuasnicú, P.S., González-Echeverría, F., Piazza, A., Piñeiro, L. \& Blaquier, J.A (1984) Epididymal proteins mimic the androgenic effect on zona pellucida recognition by immature hamster spermatozoa. $J$. Reprod. Fert. 71, 427-431.

Hamilton, D.W. (1975) Structure and function of the epithelium lining the ductuli efferentes, ductus epididymides and ductus deferens in the rat. In Handbook of Physiology; Male Reproductive System, Section 7, Vol. V, pp. 259-302. R. O. Greep \& D. N. Hamilton Eds. Am. Physiol. Soc. Washington, D.C.

Hinton, B.T. \& Setchell, B.P. (1981) Micropuncture and microanalytical studies of rhesus monkey and baboon epididymis and the human vas deferens. Am. J. Primatol. 1, 251-256.

Holt, W.V. (1982) Functional development of the mammalian sperm plasma membrane. Oxford Rev. Reprod. Biol. 4, 195-240.
Horan, A.H. \& Bedford, J.M. (1972) Development of the fertilizing ability of spermatozoa in the epididymis of the Syrian hamster. J. Reprod. Fert. 30, 417-423.

Hoskins, D.D., Johnson, D., Brandt, H. \& Acott, T.S. (1979) Evidence for a role for a forward motility protein in the epididymal development of sperm motility. In The Spermatozoon, pp. 43-53. Eds. D. W. Fawcett \& J. M. Bedford. Urban and Schwarzenberg, Baltimore.

Joshi, M.S. (1985) Isolation and cell culture of the epithelial cells of cauda epididymidis of the bull. Biol. Reprod. 33, 187-200.

Kierszenbaum, A.L., Lea, O., Petrusz, P., French, F.S. \& Tres, L.L. (1981) Isolation, culture and immunocytochemistry characterization of epididymal epithelial cells from pubertal and adult rats. Proc. natn. Acad. Sci., U.S.A. 78, 1675-1679.

Klinefelter, G.R., Amann, R.P. \& Hammerstedt, R.H. (1982) Culture of principal cells from the rat caput epididymidis. Biol. Reprod. 26, 885 901.

Mollenhauer, H.H. (1964) Plastic embedding mixture for use in electron microscopy. Stain Technol. 39, $111-114$.

Moore, H.D.M. (1981) Effects of castration on specific glycoprotein secretions of the epididymis in the rabbit and hamster. J. Reprod. Fert. 61, 347-354.

Moore, H.D.M. (1983) Physiological and in vitro models of sperm maturation. In In vitro Fertilization and Embryo Transfer, pp. 9-38. Eds G. Crosignani \& B. L. Rubin. Academic Press, London.

Moore, H.D.M. \& Bedford, J.M. (1979a) Short-term effects of androgen withdrawal on the structure of different epithelial cells in the rat epididymis. Anat. Rec. 193, 293-312.

Moore, H.D.M. \& Bedford, J.M. (1979b) The differential absorptive activity of epithelial cells of the rat 
epididymis before and after castration. Anat. Rec. 193, 313-328.

Moore, H.D.M. \& Hartman, T.D. (1986) In-vitro development of the fertilizing ability of hamster epididymal spermatozoa after co-culture with epithelium from the proximal cauda epididymidis. J. Reprod. Fert. 78, 347-352.

Orgebin-Crist, M.C. \& Jahad, N. (1979) The maturation of rabbit epididymal spermatozoa in organ culture stimulation by epididymal cytoplasmic extracts. Biol. Reprod. 21, 511-516.

Orgebin-Crist, M.C., Danzo, B.J. \& Davis, J. (1975) Endocrine control of the development and maintenance of sperm fertilizing ability in the epididymis. In Handbook of Physiology; Male Reproductive System, Section 7, Vol. V, pp. 319-338. Eds R. O. Greep \& D. W. Hamilton. Am. Physiol. Soc. Washington, DC.
Smith, C.A., Hartman, T.D. \& Moore, H.D.M. (1986) A determinant of $M_{r} 34000$ expressed by hamster epididymal epithelium binds specifically to spermatozoa in co-culture. J. Reprod. Fert. 78, 337-345.

Voglmayr, J.K., Sawyer, R.F. \& Dacheux, J.L. (1985) Glycoproteins: A variable factor in surface transformation of ram spermatozoa during epididymal transit. Biol. Reprod. 33, 165-176.

Wong, P.Y.D. \& Yeung, G.H. (1978) Absorptive and secretory functions of the perfused rat cauda epididymidis. J. Physiol., Lond. 275, 13-26.

Received 18 November 1985 